\title{
Effective Youth Ministry: Theology-driven in a Cultural Context
}

\begin{abstract}
Author:
Philippa Strong ${ }^{1}$

Affiliation:

${ }^{1}$ Faculty of Theology,

North-West University,

Potchefstroom Campus,

South Africa

Correspondence to:

Philippa Strong

Email:

philippa.strong@nwu.ac.za

Postal address:

154 Sol Plaatjie Street,

Potchefstroom 2531,

South Africa

\section{Dates:}

Received: 09 Oct. 2014

Accepted: 17 Mar. 2015

Published: 22 May 2015

How to cite this article: Strong, P., 2015, 'Effective Youth Ministry: Theologydriven in a Cultural Context', In die Skriflig 49(1), Art. \#1889, 9 pages. http://dx.doi. org/10.4102/ids.v49i1.1889

\section{Copyright:}

(C) 2015. The Authors. Licensee: AOSIS OpenJournals. This work is licensed under the Creative Commons Attribution License.
\end{abstract}

Read online:

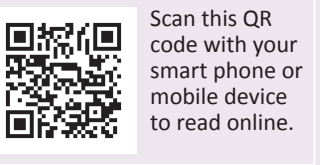

Recently Youth Ministry finds itself mostly in a crisis as it is wrongly presented. In a nutshell the crisis can be described as falling short of leading young people to become mature Christian adults. Research shows that there are a variety of contributing factors to this crisis. This article focuses on two of these contributing factors. Firstly, Youth Ministry today is skill and socially driven, rather than theology or spiritually driven. The discussion commences by indicating the importance of establishing theology as the foundation of Youth Ministry. A Christ-centric theological framework as foundation for effective Youth Ministry is proposed. The article emphasises the meaning and essence of theology, with the Sola Scriptura approach being followed throughout. The second contributing factor discussed is the issue that cultural relevance is wrongly being made the heartbeat and foundation of Youth Ministry instead of theology. The article gives culture its rightful and relevant place in Youth Ministry, without it overshadowing the foundation of effective Youth Ministry, namely theology. Postmodernism and subculture also receive attention and in the conclusion the emphasis falls on a call to return to a Youth Ministry that is theology driven in a cultural context.

Effektiewe Jeugbediening: Teologies-gedrewe in 'n Kulturele Konteks. Tans verkeer Jeugbediening grootliks in 'n krisis, aangesien dit verkeerd aangebied word. Kortliks behels hierdie krisis dat Jeugbediening daarin te kort skiet om jongmense tot volwasse Christenskap te lei. Navorsing toon verskeie faktore wat tot hierdie krisis bydra. Die artikel fokus op twee van hierdie bydraende faktore. Eerstens val die soeklig op die feit dat Jeugbediening tans metode- en sosiaal-gedrewe eerder as teologies- of spiritueel-gedrewe is. Die bespreking toon die belangrikheid daarvan om teologie en die behoefte daaraan as fondament in Jeugbediening te vestig. Die aanbeveling is dat daar 'n Christelik-teologiese raamwerk as fondament vir effektiewe Jeugbediening moet wees. Die fokus is op die betekenis en essensie van teologie met die Sola Scriptura benadering as deurgaans sentraal. Die tweede bydraende faktor tot die krisis is die feit dat kulturele relevansie in plaas van teologie verkeerdelik die hartklop en fondament van Jeugbediening gemaak word. Die artikel bied aan kultuur sy regverdige en relevante plek in Jeugbediening gebied sonder dat dit die fondament van Jeugbediening, naamlik teologie oorskadu. Postmodernisme en subkultuur geniet ook aandag. Ten slotte word die waarde van die artikel uitgelig deur die oproep tot die terugkeer na Jeugbediening wat teologies vanuit 'n kulturele konteks gedryf word.

\section{Introduction}

The article is written from a practical theological perspective whilst staying true to the Sola Scriptura principle of reformed theology (cf. North-West University 2014:1). It reflects on the crisis in Youth Ministry internationally and does not only focus on Youth Ministry in a South African context. It is, however, important to note Nel's statement $(2001: 3,8)$ that all communities, countries and denominations have been affected by this Youth Ministry approach - some sooner than others. Thus, the recent crisis in international Youth Ministry is also evident in South Africa. Osmer's model serves as a guide that directs the discussion in the article. Osmer's model asks four questions, namely What is going on?; Why is this going on?; How might we respond?; and What ought to be going on? (Osmer 2008:4; 2009:7).

Youth Ministry seems to be in the midst of a crisis, since it fails young people because of its inability to help them develop into mature Christians. This has been proven by numerous empirical data (Barna 2000; cf. Nel 2001:3; DeVries 2004:21; Shafer 2008:6; Smith \& Snell 2009:259; Dean 2010:3, 24). Research points to several causes for this problem. The aim of every ministry should be to lead people into mature Christian adulthood - making disciples of Christ (cf. Mt 28:19). It is therefore of utmost importance that this crisis should be investigated and addressed. The value of this article lies in the fact that it focuses and aims to address two of the contributing problems 
to the current crisis in Youth Ministry. This crisis in Youth Ministry answers Osmer's descriptive question, namely 'What is going on?' (Osmer 2008:4; 2009:7). The first problem that will be addressed is the fact that Youth Ministry today is skill and socially driven, rather that theology or spiritually driven (cf. Purves 2004:3; cf. also King 2006:11; cf. also Barna 2000; cf. Dean 2010:24). The second problem that will be focused on is the one of using cultural relevance instead of theology as foundation in Youth Ministry (Dean 2001a:15; cf. Mueller 2007:17). These problems are part of the multi-dimensional answer to Osmer's interpretive question: 'Why is this going on?' (Osmer 2008:4; 2009:7).

The fact that Youth Ministry of today is skills and socially rather than theologically or spiritually driven, is addressed by offering a theological framework for effective Youth Ministry that focuses on the meaning and essence of theology. The dilemma of cultural relevance being used as foundation for Youth Ministry instead of theology is addressed by giving culture its rightful and relevant place in Youth Ministry without making it the foundation or allowing it to overshadow theology. These solutions are offered in answer to Osmer's pragmatic question, 'How might we respond?' (Osmer 2008:4; 2009:7).

The crisis in Youth Ministry that answers to Osmer's descriptive question, 'What is going on?' is the direct opposite of the answer to Osmer's normative question, 'What ought to be going on?' (Osmer 2008:4; 2009:7). The aim of every ministry should be to lead people of all ages into mature Christian adulthood - making them Christ's disciples (cf. Mt 28:19).

The purpose of this article is thus to propose that effective Youth Ministry should remain theology driven within its cultural context.

\section{This crisis in Youth Ministry has to be addressed}

Any crisis in life leaves one with a choice. One can either pretend that nothing is wrong or try to change things that need to be change. If the crisis in Youth Ministry of not being effective in leading young people into mature spiritual adulthood is ignored, results will stay the same and only a few of today's youth will be led into a lasting relationship with God that continues into their adulthood. Ignoring the fact that change is necessary implies a head-in-the-sand mentality (cf. Stone 2010:11). Recent ground-breaking research by the Barna Research Group in 2007 and 2008, LifeWay Research in 2008 and Christianity Today's NationalChristianPoll.com in 2009 has revealed that such a head-in-the-sand mentality is one of the top five 'ministry killers' (cf. Stone 2010:30). The alternative is to ask the most important question that any leadership or church could ask, 'What does God want us to do?' (cf. Malphurs 2009:13; cf. Osmer 2009:7). In others words, 'What ought to happen in Youth Ministry?' (Osmer 2009:7).

\section{Youth Ministry today is skills and socially driven, rather than theology or spiritually driven}

The first problem under the magnifying glass in this article is perfectly summarised by Purves (2004) when he states:

Ministry today is skill-driven, rather than theology-driven, and it seems to incorporate little of the dynamically practical nature of theology insofar as it speaks about who God is and what God does. (p. 3)

This crisis in Youth Ministry is confirmed by George Barna (2000) who found that, although secondary and high school students attend church frequently, only one out of three teenagers plans to attend church when they are adults (cf. Smith \& Snell 2009:259; cf. also Dean 2010:3). Barna (2000) concludes that this is the lowest level of expected participation among teens recorded ... in more than a decade' (cf. also Jones 2001:63). Shafer (2008:6) confirms this finding when he says that his final analysis of the results of youth ministry impact shows that lasting impact of youth ministry on the lives of youth seemed to be measured in months, not years.

Dean (2010:4) says that the The National Study of Youth and Religion of Regnerus, Smith and Fritsch (2003) reveals a faulty concept of theology in American churches: it is seen as a do-good, feel-good spirituality that has little to do with the Triune God or with loving Jesus Christ in the long run. Dean (2010:6) concludes that the church has not succeeded in conveying 'faith' to young people. The research discovered that religious participation by teenagers is often motivated by relational opportunities rather than by the promise of spiritual development. The most important motivation for teenagers to attend church-related gatherings seems to be the possibility of making and retaining friendships, rather than deepening their faith.

\section{Theology needed as foundation in effective Youth Ministry}

Although the social sciences have much to contribute concerning our understanding of, and response to people in the process of pastoral change, pastoral theology must be clear that the Gospel and not the social sciences provides the foundation for pastoral work (Borgman 2013:7; Purves 2004:30; cf. also Anderson 2007:174; cf. Cartledge 2003:16).

The relative lack of interest in maintaining church ties in the future reflects how youths experience churches. Barna's poll found that the youth of the day do not perceive the church as particularly helpful. He describes this perception as a poor projection of Christianity indeed (cf. Barna 2000; cf. also Dean 2010:24). Shafer (2008:15) agrees and states that 'most decisions to walk away from the Christian faith aren't based on God or Jesus or anything the Word says about either, but on a poor projection of Christianity' (cf. also Senter III 2010:36). 
Christianity's main components are described as a search for God who is revealed in Christ and an encounter with the same God through Holy Spirit, which leads to transformation (McGrath \& McIntosh 1998:33-34). Dunn and Senter III (1997:50) describe these two aspects of theology and their interaction with each other when they state that the depth of one's personal relationship with God is directly affected by the authenticity of one's factual knowledge of him (cf. Heb 11:17-19; cf. also Heidelbergse Catechismus in De Bruyn 1997:43; cf. also Venter 1991:47). Wilhoit (1991:42) describes the 'true knowledge' of God as 'facts, feelings, and proper relationship' (cf. also Dunn \& Senter III 1997:48). He elaborates on 'true knowledge of God', saying that facts are learned primarily through studying God's Word, feelings experienced in response to who we have come to understand him to be, and a personal relationship with God that has been formed from 'shared experiences, commitment, and communication'. All these facets comprise an authentic portrait of knowledge of God (Wilhoit 1991:38; cf. also Dunn \& Senter III 1997:48).

In the above consideration of what Christianity is all about, it is evident that the 'poor projection of Christianity' is the result of a lack of theological grounding in Youth Ministry.

Shafer (2008:13) relates how a leading youth minister told him that the area where Youth Ministry has lost ground the most with young people is the inability of it to ground them in God's Word. We should not merely 'spray on the Word on our youth'; they need to be drenched with the Word (cf. Shafer 2008:9). Purves (2004:204) has the same view when he states that God draws near through the ministry of the Word of God, which leads to a twofold outcome. It exhorts people to accept the good news of salvation and encourages them towards faithful living.

King (2006:11) states that the core of successful Youth Ministry is theology - teaching young people the Word of God and guiding them into his presence.

\section{Youth Ministry yearns for a theological grounding}

Historically speaking, Youth Ministry did not really exist before the Industrial Revolution of the mid-19th century (cf. Nel 2001:3). It is actually for quite a whilst now that attempts have been made to give Youth Ministry a theological grounding (Nel 2001:3; cf. also Dean 2001a:15). Both theology and society have been calling for a radical change in traditional Youth Ministry for longer than a century (Nel 2001:3; cf. also Senter III 2001:xi). King (2006:11) strongly states that it is time for a thorough examination of traditional Youth Ministry philosophy and praxis.

According to Dean (2001a:15) we are entering into 'a theological turn in youth ministry'. She describes it as an era in which theological reflection is becoming the norm in Youth Ministry instead of the exception (cf. also Borgman 2013:7).
Youth Ministry is thus in a place where people not only realise that it has to be driven theologically, but it also yearns for it to become a reality.

\section{Pointers for a theologically driven Youth Ministry}

In order to promote a theologically driven Youth Ministry, it is important to understand and define practical theology.

Defining the term theology: The term theology is derived from two Greek words, namely theos, meaning 'God', and logos, meaning 'word'. Thus, theology means a study conducted on the Word of God to try and understand God's nature and how he reveals himself (cf. North-West University 2014:1).

Nel (2001:5) indicates that practical theology generally asserts that the gospel is primarily about the kingdom of God (the grace message of God's self-revelation and God's dynamic reign) that has come and is yet to come (cf. also Stassen \& Gushee 2003:24-26).

Theology is all about expanding God's Kingdom under the direction of the Lord Jesus, who is coming and who is present through the power and work of the Holy Spirit (Anderson 2006:11).

\section{Theology is firstly about a personal relationship with God}

1 John 1:1 states clearly that God himself is also the Word and therefore theology cannot and should not be only a study of the written Word of God, but also practical knowledge of God as person, as he, in Jesus Christ, became the Word (NIV; cf. also Stevens 1999:12). Purves (2004:xviii) embraces this biblical truth when he aptly states that practical theology is not a neutral knowledge of God, but firstly a personal knowing of God (Purves 2004:xviii). He also states that there is no neutral knowledge of God (Purves 2004:xxvi). Anderson (2004:7), who also claims the importance of personally knowing God, argues that the tendency is to fasten minds on abstract concepts of God rather than on a personal knowledge of God, specifically in academic theology (cf. McGrath 1990:174; cf. also Lewis, McGrath \& Packer 1996:14; Stevens 1999:17). Anderson boldly states that if we see God as an abstract God, we not only divest God of soul, but we produce a theology that is bereft of soul (Anderson 2004:7). He drives this point home when he vividly describes that a good bit of traditional theology becomes stones instead of bread for those who hunger for the Word of God, as of this very reason Jesus Christ himself said, 'I am the bread of life ...' (Jn 6:35; cf. Mt. 7:9; cf. also Anderson 2004:7).

In the same vain Stevens (1999:141) writes that the ministry of God is not merely for God; it is relational and characterised by God's love for a dying world. Fields and Robbins (2007) agree with the following profound statement: '... there are 
hurting kids everywhere dying to know the good news of God's love'. As Dunn and Senter III (1997) explain clearly that:

God is thus seen as both source and object in theological learning. Viewed from this perspective, theology is still challenging, but far less intimidating. A child naturally wants to know his Father well. (p. 49)

Dunn and Senter III (1997:47) also support the importance of knowing God personally as the main essence of theology when they say that the true final purpose of theological study is to know God. It is clear that pastoral theology as Christian theology in general, centres on personally knowing God, and its language must reflect this fact (cf. also Anderson 2004:8; cf. also Purves 2004:xxvi).

King (2006:11) urges that an authentic atmosphere should be created for young people where they can seek the truth and discover who they are in Jesus Christ. He says that the ultimate goal of Youth Ministry should not be only to get the youth to attend meetings about Christ; it should first and foremost be about getting youth to connect to Christ (cf. also Dunn 2004:17). Dunn (2004:17) confirms the 'heartbeat of youth ministry' when he states that the ultimate goal in every home and Youth Ministry should be to pull youth into a place where they have developed an intimate relationship with God.

Blaise Pascal (n.d.), the French mathematician-philosopher, rightfully states that 'There is a God-shaped vacuum in the heart of every man which cannot be filled by any created thing, but only by God, the Creator, made known through Jesus.' Barna's (2000) research proves this God-shaped vacuum in the hearts of teenagers, as it reveals that they have a simultaneous desire to be portrayed as religious people whilst not being deeply devoted to one (cf. also Dean 2010:4). As Barna (2006:30) beautifully put it: 'Every human being was created by God primarily to know Him, love Him, and serve Him.'

It is strongly agreed with that not only does the youth need to learn about Jesus in Youth Ministry, but time should be scheduled where they can spend personal time with God in order to know him. Youth leaders and parents should demonstrate their own personal relationships with God. Having a personal relationship with Jesus is not something that can be taught; it is only something that can be caught. The Bible gives amazing images of having a personal relationship with God. When we seek him, we will find him ... When he knocks, and we open, he will enter and we will have a feast with him (cf. Rv 3:20; Jr 29:13-14).

\section{All theology is practical theology}

Purves (2004:8) brilliantly argues that there is no uninvolved God and therefore there is no such thing as impractical theology. 'All theology, all knowledge of God, by virtue of the subject matter - the acting God - is inherently a practical theology or a practical knowledge of God.'
The Bible states in John 1:1 that God himself is the Word, and God is an acting God.

Purves (2007) elaborates on the profound statement quoted above in a later work by saying:

It is not we by our actions who make theology practical (the old notion of practical knowledge as applied theology), but it is God, by virtue of what God does, who makes knowledge of God inherently a practical knowledge. (p. 9; cf. also Stevens 1999:13-14)

This statement is of extreme importance, as it is often thought that the ministry of human beings as such have the authority to make theology practical, which automatically leads to the wrong implication that praxis in theology is a human initiative and not God's. He continues to say that theology really in itself is nothing else than 'who God is', 'what God does' and 'all church practise is properly understood as sharing God's practise' (Purves 2004:3). It is not the actions of the church that make theology practical, it is God by virtue of what he does that makes theology practical (cf. Purves 2004:xxv-xxvi, 3, 8-9; Anderson 2004:8).

Purves (2004:152) writes that pastoral ministry should be converted from pragmatism to an approach of sharing in the work or ministry of God in, through and like Jesus Christ (cf. Col 3:3). Root and Dean (2011) agree with Purves when they make the bold and absolutely true statement that:

Our own ministries in the world, then, are only truly ministries if they are connected to God's continued Ministry, and theology is only constructive (and helpful) if it is done in the context of God's continued Ministry in the world. (p. 40)

It is thus important that effective Youth Ministry should be all about connecting with God and having a Godactualised approach rather than a self-actualised approach to ministry (cf. also Purves 2004:152). Ministry should be theologically driven and should teach the youth about a personal relationship with the triune God, his Word and his Kingdom - his gracious message of self-revelation and his dynamic reign.

\section{God as Trinity}

Trinity can be described as the doctrine that demonstrates to us the love of God the Father in giving his Son, the love of God the Son in giving himself, and the love of Holy Spirit in his work of regenerating man so that we may be able to take hold of the love of the Father through his Son (Anon n.d.). As Anderson (2004:8) concludes, 'It is only as we reflect on God's ministry as Creator, Reconciler and Redeemer that we gain insight into the soul of theology' (cf. also Nel 2001:5).

The theologians of the Early Church tried to describe the meaning of 'Trinity' by comparing it with a distinctive Greek dance, perichoresis, where at least three people dance in a 
circle. They move in a beautiful pattern of motion, going in and out, going faster and faster, whilst staying in perfect rhythm and in sync with one another. The dance becomes so fast that when spectators look at them, it becomes a blur. Their individual identities become part of a larger dance. The Early Church fathers and mothers looked at that dance (perichoresis) and said: 'That's what the Trinity is like.' It is a harmonious set of relationships in which there is mutual giving and receiving. This relationship is called love, and that is what the Trinity is all about. The perichoresis is the dance of love (Anon n.d.). Anderson (2004:24) also describes God's ministry to the world as an act of love when he writes 'It is the ministry of God toward the world that reveals the being of God as the one who loves the world' (Jn 3:16; cf. also Cartledge 2003:19).

God, being described as 'Triune God', attempts to express the mystery of 'Who God is', as God is self-given to be known by us in, through and as Jesus Christ and in the Holy Spirit. As such it brings us into communion with God (Purves 2004:30; Lotter 2005:500). Karl Barth (1975:489) answers the question about who God is like follows: 'It is He who gives Himself to humanity as Trinity.' (cf. also Purves 2004:31).

When the doctrine of the Trinity becomes marginalised, in this case specifically in Youth Ministry, believers lose sight of the fact that Christian faith, life and ministry are ultimately participatory (and not simply a matter of the right legal status before God) and should be taught to the youth in that way. The lack of this insight results in believers losing sight of the fact that Christian faith is ultimately about union with Christ in the Spirit. The neglect of focusing on the Trinity causes the Christian understanding of the Gospel to focus on forgiveness. However, on the cross Christ did not only forgive us, but also restored us to union and communion with the Father through the Son in the Spirit. All of Christian faith, life and practice are therefore participatory. Furthermore, lack of understanding and failure to embrace God as Trinity can lead to the understanding that God is a solitary divine dictator. Seeing God as a dictator, or in this case teaching youth that God is a solitary divine dictator, produces suspicious, critical, harsh, cold and condemning youth. On the other hand, if the teaching in Youth Ministry embraces the Triune God who is Father, Son and Holy Spirit, it will result in the youth growing, showing and spreading the kindness, goodness and joy that they experience from the Triune God in their personal relationship with him (cf. Anon n.d.)

The doctrine of the Trinity does not just tell us about God, it is also the basic framework of meaning in which we, as Christians, live our lives (Purves 2004:30). Practical theology and pursuance the glory of triune God can and should be the core of effective Youth Ministry (cf. also Cordeiro 2011:2223). A Trinitarian theology is thus inherently a practical theology in that it is a knowledge of God's action grounded in God's being, says Purves (2004:xxv; cf. also Anderson 2004:8).

\section{Mission of God: Jesus Christ is the Missio Dei of God}

Practical Theology is theology concerned with action (Purves 2004:xxv). Firstly it is concerned with God's action, the Missio $D e i$, who is Jesus Christ, and secondly with the action or praxis of the church, which arises from her faithful communion with God and shares in his practise (Purves 2004:xxv, xviii; Root \& Dean 2011:40).

The church mission is not a new invention; it is the ministry of God that makes our ministries possible and practical. His Missio Dei enables the churches' ministry (cf. also Purves 2004:22; cf. also Cartledge 2003:19).

Purves (2004) summarises the meaning of Jesus Christ as God's mission Dei as follows:

... it is a gracious sending and becoming, because as God with us He comes as God for us, to do for us in the flesh of our humanity what must be done to restore us to union and communion with the Father. (p. 24)

In the Bible we read that after Christ left this earth, God sent the Holy Spirit to the world (Jn 16:5-11). At the moment someone is reborn, that person receives the gift of Holy Spirit, who then lives in, and leads the person into all truth (Ac 2:38; Jn 16:12).

Purves concludes (2004:xviii) that Jesus Christ is the Missio Dei of God to and for us. He says that this is the grounds and the basis of theology for churches' ministries - in this case Youth Ministry. The Missio Dei message may be summerised in the benediction, 'The grace of the Lord Jesus Christ, the love of God, and the communion of the Holy Spirit be with all of you' (2 Cor 13:13).

Pastoral Theology has but one subject, Jesus Christ, and no content other than 'the faith that was once for all entrusted to the saints' (Jude 3; cf. Purves 2004:3; Horton 2013). As Purves (2004:154) put it: 'Pastoral care has no other content or legitimization than Jesus Christ.'

The heart of Youth Ministry should always be about Jesus Christ just as church should always be about Jesus Christ, about what he did for us, how he feels about us and that he wants to be known by us (cf. Root \& Dean 2011:14; cf. also Purves 2004:ix).

\section{Contributing factor to the crisis: Youth Ministries have come to use cultural relevance as foundation instead of theology}

In some instances Youth Ministries have been built on culture as foundation rather than on theology (Dean 2001a:15). One could say, that the outside appearance, culture, became more important than theology (cf. Anderson 2004:xviii; Purves 2004:xxvi). Sometimes Youth Ministries 
focuses on cultivating a Christian culture in youth, whilst a Christocentric message and what it entails, are totally neglected. This focus in Youth Ministry results in youth saying the right christianees, sing the right songs, wearing What will Jesus do (WWJD) bracelets and even doing the right things, but their hearts are far from God as they are not having a personal relationship with Christ (cf. Mt 15:8).

Dean (2001a:15) concludes that the difference between youth leaders who thrive in Youth Ministry and those who collapse under its weight lies in the substance of their foundations: did they build the Youth Ministry on a theologically sound basis or on a basis of cultural relevance? Although understanding that culture is an important part of connecting to young people in Youth Ministry, it should not be the foundation or heart of the ministry.

\section{Defining a proper place and rank for culture in effective Youth Ministry}

Culture is defined by Strommen and Hardel (2008:269) as the way of living that has become normative for a group of human beings. They continue to state that culture includes music, art, media and intellectual stimuli that contain and communicate norms and values. Mueller (2007:17) says that a variety of factors combine in today's world to make the voice of culture far more compelling and attractive to children (cf. also Dobson 2012:12).

A biblically grounded theology of cultural engagement that reflects both the Lordship of Christ over all creation and the special mission and calling of the church is outlined by Van Drunen (2012) in his book, Living in God's Two Kingdoms.

Understanding cultural engagement in Youth Ministry is thus very important in order to fulfil the calling of the church and to connect to young people. However, culture should never be the foundation or heart of Youth Ministry (cf. Dean 2001:15a; cf. also Mueller 2007:17). It is inevitable that for Youth Ministry to be effective, the culture of our day should not only be understood, but also be given its proper place and rank (cf. also Linhart \& Livermore 2011:28, 31).

Understanding the culture of the time is very important when we build a framework for effective Youth Ministry, as we need to communicate the truth to young people in a way that speaks to their hearts. The church should always make an effort to connect culturally to the youth, although it should not be the most important aspect of Youth Ministry (cf. also Carson \& Keller 2012; cf. also Dean 2001a:15). Linhart and Livermore (2011:32) reminds us that cross-cultural ministry requires an ability to address issues with a theological sensitivity.

Smith and Snell (2009:33) also emphasise this point when they say that it is absolutely crucial to understand the religious and spiritual worlds of the youth within the broader context of the larger cultural worlds they live in.
DeVries (2004:193) calls Christians to be willing to assert their cultural preference for traditional norms such as marriage and the two-parent home if a situation requires it (cf. also McManus 2003:239-241). As McManus (2003:241) beautifully describes the churches' relevant engagement with culture by saying that when the church is born from the heart of God, it is less about marketing and more about the passion to become all things to all men (may I add, without compromising the Word of God) in order that some might be saved.

\section{Postmodernism}

'The cultural era we find ourselves in, is called Postmodernism' (Jones 2001:4). Many call it the most important cultural shift in 500 years; some call it the Second Reformation.

\section{Common ground between Christians and postmodernism}

Anderson (2007:3) identifies three fields of common ground between Christians and postmodernism.

Firstly, Christians can agree that postmodernism rightly rejects the myth that all knowledge is objective - we are involved as human beings, on a personal and moral level, in everything that we know. Objective human thought is not possible.

Secondly, Christians can agree with postmodernists in acknowledging the importance of communities in our understanding of truth. None of us are autonomous individuals like islands, cut off from influences of social traditions. Lawrence (2002:83-84) confirms this importance of relationships in faith experience when he says that, in order to make an impact, the church should be willing to engage in authentic and genuine friendships (cf. also Steyn \& Lotter 2006:535-555; Theron \& Lotter 2008:307).

Thirdly, postmodernism rightly emphasises the significance of narrative and story - human beings cannot live without the meaning and purpose that such stories give (cf. also Mueller 2007:110). Most of the Bible is made up of narrated history and in the New Testament Jesus Christ teaches people through stories and parables as he realised the power of teaching through narration. Today, in our postmodern context, the power of teaching through stories and parables are still powerful and relevant (cf. also Smith 2006:76-77).

\section{Important characteristics of postmodernism, its influence and how we should address it in effective Youth Ministry}

\section{Rise of spirituality}

One of the noteworthy characteristics of the postmodern or post-Christian world is the dramatic rise of spirituality. As Putman (2008:4) bluntly put it, 'Many people today are on spiritual journeys, but they are far removed from Christ 
and the church.' In the same vein Swartz (2004:83-85) remarks that, although there is a high degree of religiosity amongst South African youth, there are various factors that do not correlate with what might be expected of religiously committed youth. Lotter and Thompson (2005:709) mention that there is an increase in biblical knowledge in this postmodern era. Prepositional truth is out and mysticisms are in. In our postmodern world religious diversity as well as philosophical and religious pluralism is at the order of the day (Lotter \& Thompson 2005:708). People are not necessarily put off by a religion that does not 'make sense'. They are more concerned with whether a religion can bring them into contact with God. (Jones 2001:63; cf. also Strommen \& Hardel 2008:79, 139; Poling 2002:85). Lawrence (2002:83) says that in the postmodern context in which we find ourselves it is not enough for the church to only proclaim the kingdom of God, it should also demonstrate the kingdom of God, for example praying for healing of the sick, offering wholeness to the spiritually lost and kindness to those who need it (cf. also Theron \& Lotter 2008:307).

People want to find God; they want to have contact with him. No more gimmicks, no more church play - an introduction to a God that is alive, almighty, a God who wants to be in relationship with them is the God today's youth wants to find.

Dean (2001b) describes this dramatic rise of spirituality aimed at teenagers when they say:

Postmodern society pelts young people with gods from every side - gods of good times, gods of wealth, gods of ambition, gods of position, and countless others - all claiming salvation or your money back. (p. 29)

Youth Ministry should all be about connecting the youth to the only, loving and loveable God who is alive, powerful and real. Prince (2009:157) strongly remarks that teaching youth about God will not do, we should also demonstrate a love relationship with God.

\section{Individualism}

Strommen and Hardel (2008:270) say that in postmodernism there is an emphasis on individuality rather than uniformity (Anderson 2007:162).

Long gone are the days that the youth felt involved and important, because they all wear the same t-shirt. Not even my child at primary school likes the idea that everybody has the same t-shirt for the school's fun walk! The youth of our day would not be won for Christ if they need to fit into a certain mould pertaining to their dress code, their hair, et cetera. In effective Youth Ministry these factors are of secondary importance. What are really important are their souls. It does not really matter if your son wears an earring; what really matters is his relationship with Christ. We will much easier win the youth for Christ if we embrace them as individuals rather than trying to fit them into moulds and expect them to look like Christians are traditionally believed to look like. Christ himself said that when we are committed to him, he will change us from the inside out! (Heb 8:10). It is therefore important to focus on the souls of the youth rather than on their outer appearance: the tattoos, nose rings or black nail polish, since these things are of lesser importance.

\section{Reached by way of images and stories}

In the current postmodern era people are reached more by way of images and stories than propositions and principles (cf. Smith 2006:76-77). Kingma and Lotter (2002:310) confirm this notion when they say that postmodern people are involved in a quest for meaning in life, because the known orders and -isms failed miserably (cf. also Theron \& Lotter 2008:307; cf. Smith 2006:76-77). People are more intuitive than logical. It is thus important to adapt to this reality in bringing the gospel to people - in this case, young people. Live your story if you want to reach people in this cultural era (cf. Putman 2008:107).

The challenge to Youth Ministry in this postmodern era is to bring the gospel in a fresh and artistic way by using stories, other art forms as well as the developing technology - without losing the truth of the gospel. It is a fact that youth, whether a toddler or teenager, loves stories (cf. also Mueller 2007:110). The importance of incorporating images and stories in our messages in Youth Ministry thus cannot be ignored. Even expository preaching fails if it does not tie every text into the great story and mission of Jesus Christ (cf. also Carson \& Keller 2012).

\section{Living in a competition driven culture}

The culture of our day rewards money, power and prestige, not the honest businessman, the devoted husband or the involved father. As a result many fathers become sports fanatics or workaholics, convincing themselves that more hours at the office will give them real success (Boteach 2006:21, 218; cf. also DeVries 2004:29). The result is that children are being raised with a warped view of family life, power, prestige and security. If we do not protect our children against negative influences, they will be corrupted by those influences (Boteach 2006:5).

It is therefore of utmost importance to teach and demonstrate to youth what family life and success is in God's eyes to protect them against this warped view of family where the success of family life is directly compared to what families own - even if the parents are never home. Leaders should further speak out against this 'culture of competition' to teach youth what is really important, namely that our security should be in God and not in property or positions.

\section{Perversion of the natural progression of childhood}

In today's culture a real perversion of the natural progression of childhood - early onset adulthood - is very general (Boteach 2006:13; cf. also Senter III 2010:35; Dunn \& Senter 
III 1997:513). Medved and Medved (1998:3) also point to this perversion and say that in every corner of contemporary culture, childhood innocence is under assault. Children are no longer smoking chocolate cigarettes, rocking and changing their dolls and playing dress-up pretending that they are adults. Children presume real adult roles with none of the maturity that comes with adulthood. They are paying real adult prices in teenager pregnancies, drug overdoses, suicides to name but a few. Padded underwire bra's are even available for pre-school girls as young as 4 years old and there are parents who buy it (cf. Dermody 2008; cf. also Pinkshotgungal 2008; Parniak-McCallum 2011).

Boteach (2006:13) shows in his research that the reason why children and youth are so unhappy overall is because of the fact that they are not really children at all, but rather cynical adults in disguise. Early onset of adulthood is the main problem of the youth of our day (Boteach 2006:2,13). Instead of being afraid to miss out on their childhood years, children seem to fear missing out because of their childhood years. This problem should be addressed by God-fearing parents and Youth Ministries wanting to make a real impact. Boteach (2006:20) stresses the responsibility of parents to inspire their children to explore the joys of childhood instead of trading it for premature adulthood (cf. also Dunn \& Senter III 1997:509).

According to Boteach (2006:19) the greatest gift of real childhood is the ability to internalise the critical phase of childhood and carry it into the future. Boteach (2006:4) says that we must return our children to childhood by giving them a solid foundation of love and discipline, coupled with the inspiration to grow. Dunn and Senter III (1997:495) also make this call for children to return to childhood. They say that children and teenagers alike want to be hold in a family where the love is secure, where they know they belong, where there is someone older and stronger to carry some of the load.

Allowing children to be children and not permitting youth to buy into premature adulthood, which is wrongly projected as ' $\mathrm{Cool}^{\prime}$ ', is the answer to this dilemma. What is needed is parents and youth leaders with backbone who can stand up against youth alcohol abuse, pre-schoolers wearing bra's, girls with heavy make-up, teenage sex and so on, giving youth the love and security they really crave at home and in youth groups, teaching them the wonderful lesson of Ecclesiastes that God made everything, also childhood, beautiful in its time (cf. Ec 3:11).

\section{The risk to create a subculture}

In the process of reaching people for Christ it is important not to create a new subculture where we are always busy with christianees and spending time with Christians (Putman 2008:102). Strommen and Hardel (2008:19) confirm this negative characteristic of traditional Youth Ministry when they state that the current Youth Ministry subculture paradigm has subtly conveyed the impression that faith is nurtured only in church buildings. Jesus prayed to God not to take the disciples out of this world, but that he will protect them from the evil one and send them into the world (Jn 17:14-19). The Bible is thus very clear on this issue. God wants his children, also the Christian youth, to be salt and light in this world in every facet of their lives (Mt 5:13-16).

\section{Epilogue}

This article primarily calls for a return to theology in all aspects of Youth Ministry (1 Jn 1:1). In an effort to motivate this call, some valuable truths are highlighted and discussed to help Youth Ministry return to theology.

The starting point is practical theology and the essence of theology, which centres on the importance of knowing God personally and having an intimate relationship with him. All theology is practical, as God is an acting God. Effective Youth Ministry should thus have a God-actualised approach to ministry, instead of a self-actualised approach. The discussion of God as a loving Trinity emphasises the essence of theology as a loving relationship between Father, Son and Spirit based in the Trinity's loving relationship with mankind. Jesus Christ as God's Missio Dei reminds us that without him, it would not be possible to stand in relationship with God. Therefore, the message of effective Youth Ministry can be nothing else but Christ-centric.

The importance of understanding culture in Youth Ministry is stressed and it is placed in a cultural context without making it the foundation of Youth Ministry instead of theology. As part of the acknowledgement of this fact, the article follows with a discussion on the characteristics of postmodernism and it concludes with a warning not to create a subculture.

\section{Acknowledgements Competing interests}

The authors declare that they have no financial or personal relationship(s) that may have inappropriately influenced them in writing this article.

\section{References}

Anderson, R.S., 2004, The Soul of God: A Theological Memoir, Wipf \& Stock, Eugene. Anderson, R.S., 2006, An Emergent Theology for Emerging Churches, IVP Books, Illinois.

Anderson, R.S., 2007, Something Old, Something New: Marriage and Family Ministry in a Postmodern Culture, Wipf \& Stock, Oregon.

Anon, n.d., The Dance of Love: Perichoresis, viewed 21 August 2014, from http:// musicanddancing.wordpress.com/perichoresis/

Barna, G., 2000, Teenagers Embrace Religion But Are Not Excited About Christianity, viewed 07 June 2012, from http://www.youth-ministry.info/articles. php5?type $=2 \&$ cat $=20 \&$ art_id $=38$

Barna, G., 2006, Revolution: Worn-out on church? Finding vibrant faith beyond the walls of the sanctuary, Christian Art Publishers, Vereeniging.

Barth, K., 1975, Church Dogmatics, I/1, rev. edn., ed. G.W. Bromiley \& T.F. Torrence, transl. G.W. Bromiley, T\&T Clark, Edinburgh.

Borgman, D., 2013, Foundations for Youth Ministry: Theological Engagement with Teen Life and Culture, Baker Books, Grand Rapids.

Boteach, S., 2006, Parenting with Fire: Lighting the Family with Passion and Inspiration, New American Library, New York.

Carson, D.A. \& Keller, T., 2012, 'Gospel-Centered Ministry', in D.A. Carson \& T. Keller (eds.), The Gospel as Center, viewed 06 June 2012, from http://issuu.com/ crossway/docs/2012academiccatalog/7 
Cartledge, M.J., 2003, Practical Theology: Charismatic and Empirical Perspectives, Paternoster Press, Carlisle. (Studies in Charismatic and Pentecostal Issues).

Cordeiro, W., 2011, The Irresistable Church: 12 Traits of a Church Heaven Applauds, Bethany House, Minneapolis.

Dean, K.C., 2001a, 'Theological Rocks - First Things First', in K.C. Dean, C. Clark, D. Dean \& K.C. Rahn (eds.), Starting Right: thinking Theologically about youth ministry, pp. 15-23, Zondervan, Grand Rapids.

Dean, K.C., 2001b, 'Fessing Up: Owning Our Theological Commitments', in K.C. Dean, C. Clark, D. Dean \& K.C. Rahn (eds.), Starting Right: thinking Theologically about youth ministry, pp. 27-40, Zondervan, Grand Rapids.

Dean, K.C., 2010, Almost Christian: What the Faith of Our Teenagers is Telling the American Church, Oxford University Press, Oxford.

De Bruyn, P.J., 1997, Jou enigste troos: Die Heidelbergse Kategismus vir die hedendaagse mens, PU for CHE, Potchefstroom.

Dermody, C., 2008, 'Padded Bras for 4-Year-Olds?', in The Stir: Fresh talk always brewing, viewed 02 August 2012, from http://thestir.cafemom.com/toddler/1946/ Padded_Bras_for_4_Year

DeVries, M., 2004, Family-based Youth Ministry, 2nd edn., InterVarsity Press, Illinois.

Dobson, J., 2012, Dobson's Handbook of Family Advice: Encouragement and Practical Help for Your Home, Harvest House, Eugene.

Dunn, S., 2004, Bored with God: How Parents, Youth Leaders and Teachers Can Overcome Student Apathy, InterVarsity Press, Downers Grove.

Dunn, R.R. \& Senter III, M.H., 1997, Reaching a Generation for Christ, Moody, Chicago.

Fields, D. \& Robbins, D., 2007, Speaking to Teenagers: How to Think About, Create, and Deliver Effective Messages, Zondervan, Grand Rapids.

Horton, M., 2013, Preaching Christ Alone, viewed 20 August 2013, from http://www. monergism.com/thethreshold/articles/onsite/preachChristalone.html

Jones, T., 2001, Postmodern Youth Ministry, Zondervan, Grand Rapids.

King, M., 2006, Presence-Centered Youth Ministry, InterVarsity Press, Illinois.

Kingma, B.R. \& Lotter, G.A., 2002, 'Begrip vir die lewenskonteks van mense as 'n vereiste vir pastorale begeleiding', Koers 67(3), 309-328. http://dx.doi. org/10.4102/koers.v67i3.375

Lawrence, B., 2002, 'Starbucks spirituality', Leadership Fall, 81-84.

Lewis, D.M., McGrath, A.E. \& Packer, J.I., 1996, Doing Theology for the People of God: Studies in Honor of J.I. Packer, InterVarsity Press, Illinois.

Linhart, T.D. \& Livermore, D., 2011, Global Youth Ministry: Reaching Adolescents Around the World, Zondervan, Grand Rapids.

Lotter, G.A., 2005, 'Die werk van die Heilige Gees volgens 2 Korintiërs en die moontlike pastorale implikasies daarvan', In die Skriflig 39(3), 487-504. http://dx.doi. org/10.4102/ids.v39i3.399

Lotter, G.A. \& Thompson, G.G., 2005, 'Acts 17:16-34 as paradigm in responding to postmodernity', In die Skriflig 39(4), 695-714. http://dx.doi.org/10.4102/ids. v39i4.410

Malphurs, A., 2009, Stategic Disciple Making: a Practical Tool for Successful Ministry, Baker Books, Grand Rapids.

McGrath, A. \& McIntosh, M.A., 1998, Mystical Theology, Blackwell, Oxford.

McGrath, A., 1990, The Enigma of the Cross, Hodder \& Stoughton, London.

McManus, E.R., 2003, 'The Global Intersection', in L. Sweet (ed.), The Church in Emerging Culture: five perspectives, pp. 233-241, Zondervan, Grand Rapids.

Medved, M. \& Medved, A., 1998, Saving Childhood: Protecting Our Children from the National Assault on Innocence, HarperCollins, New York.

Mueller, W., 2007, Youth Culture 101, Zondervan, Grand Rapids.

Nel, M., 2001, 'The Inclusive Congregational Approach to Youth Ministry', in M.H. Senter III (ed.), Four Views of Youth Ministry and the Church, pp. 1-38, Zondervan, Grand Rapids.

North-West University, 2014, Theology on Reformational foundation, viewed 23 June 2014, from http://www.nwu.ac.za/theology-reformed-foundation
Osmer, R.R., 2008, Practical Theology: An introduction, Eerdmans Publishing Co., Michigan.

Osmer, R.R., 2009, 'Practical Theology: A Current International Perspective', paper presented at the Annual conference for the Society for Practical Theology, University of Pretoria, Pretoria, 20-22nd January.

Parniak-McCallum, N., 2011, 'Walmart: Stop selling padded, underwire bras in toddler sizes', in change.org, viewed 08 August 2012, from http://www.change.org/ petitions/walmart-stop-selling-padded-underwire-bras-in-toddler-sizes

Pascal, B., n.d., Blaise Pascal Quotes, viewed 14 June 2012, from http://thinkexist. $\mathrm{com} /$ quotation/there_is_a_god_shaped_vacuum_in_the_heart_of $/ 166425 . \mathrm{html}$

Pinkshotgungal, 2008, 'Would you get this for a four year old girl?, in Cafe mom: The meeting place for moms, viewed 06 August 2012, from http://www.cafemom. com/group/416/forums/read/6958874/Would_you_get_this_for_a_4_y_o_girl

Poling, J., 2002, 'What are they really asking?', Leadership Fall, 85-86.

Prince, J., 2009, Unmerited Favor: Your supernatural advantage for a successful life, Charisma House, Singapore.

Purves, A., 2004, Reconstructing Pastoral Theology, Westminster John Knox Press, London.

Putman, D., 2008, Breaking the discipleship Code, B \& H Publishing Group, Nashville.

Regnerus, M., Smith, C. \& Fritsch, M., 2003, A Research Report of the National Study of Youth \& Religion, viewed 14 March 2015, from http://files.eric.ed.gov/fulltext/ ED473896.pdf

Root, A. \& Dean, K.C., 2011, The Theological turn in Youth Ministry, InterVarsity Press, Illinois.

Senter III, M.H., 2001, 'Of Churches, Youth Groups, and Spiritual Readiness: The Context of the Debate', in M.H. Senter III (ed.), Four Views of Youth Ministry and the Church, pp. ix-xix, Zondervan, Grand Rapids.

Senter III, M.H., 2010, When God Shows Up: A History of Protestant Youth Ministry in America, Baker Books, Grand Rapids.

Shafer, B., 2008, Unleashing God's Word in Youth Ministry, Zondervan, Grand Rapids. Smith, J.K.A., 2006, Who's afraid of Postmodernism?, Baker Books, Grand Rapids.

Smith, C. \& Snell, P., 2009, Souls in Transition: Religious \& Spiritual Lives of Emerging Adults, Oxford University Press, Oxford. http://dx.doi.org/10.1093/acprof:0 so/9780195371796.001.0001

Stassen, G.H. \& Gushee, D.P., 2003, Kingdom Ethics: Following Jesus in Contemporary Context, InterVarsity Press, Illinois.

Stevens, R.P., 1999, The Other Six Days: Vocation, Work, and Ministry in Biblical Perspective, Eerdmans, Cambridge.

Steyn, R.S. \& Lotter, G.A., 2006, 'Veranderende tendense en die implikasie vir jongmens-verhoudinge', Koers $71(2,3,4), 535-555$.

Stone, C., 2010, 5 Ministry Killers and How to Defeat Them, Bethany House Publishers, Minneapolis.

Strommen, M.P. \& Hardel, R.A., 2008, Passing on the Faith: A Radical Model for Youth and Family Ministry, Saint Mary's Press, Winona.

Swartz, S., 2004, 'The State of Youth Research in South Africa', Journal of Youth and Theology 3(2), 75-92. http://dx.doi.org/10.1163/24055093-90000218

Theron, P.M. \& Lotter, G.A., 2008, "'Do not be yoked together with unbelievers": Challenges for Christians and the church amidst unbelievers in a post-modern context', Dutch Reformed Theological Journal/Nederduitse Gereformeerde Teologiese Tydskrif 49(3\&4), 300-316.

Van Drunen, D., 2012, Living in God's Two Kingdoms: A Biblical Vision for Christianity and Culture, viewed June 2012, from http://issuu.com/crossway/docs/2012acade miccatalog/18?zoomed=true\&zoomPercent $=119.0294788492132 \&$ zoomXPos $=0$. miccatalog/18?zoomed=true\&zoomPercent $=119.0294788$
$9798792756539235 \&$ zoom YPos $=0.2415553809897879$

Venter, C.J.H., 1991 '“Jou enigste troos”: Pastorale perspektiewe en motiewe uit die Heidelbergse Kategismus', In die Skriflig 25(1), 47-49. http://dx.doi.org/10.4102/ ids.v25i1.1365

Wilhoit, J., 1991, Christian Education \& the Search for Meaning, 2nd edn., Baker Books, Grand Rapids. 